\title{
Whole grain cereals \& millets: one of the dietary interventions for obesity management in Indian scenario
}

\section{Opinion}

Whole grain cereals \& millets (small seeded grasses) are the oldest $\&$ most economical crops known to Humans especially in developing countries like India. They had been staple part of grandparent's diet in India. They include Ragi (finger millet), Bajra (Pearl millet), Jowar (Sorghum), Rajgeera (Amaranth seed), Kangani (Foxtail millet), Jau (Barley), etc.

However these got sidelined due to green revolution, which focused on increasing yield of Rice and Wheat varieties. They were pushed by Government at Subsidy PDS (Public Distribution System). Rice in the form of parboiled \& hand pounded (ukda chawal) was consumed in Rural \& southern cities of India.

Because of Urbanisation \& Westernisation, there was/is an increase consumption of polished rice \& refined flour that took over ancient millets \& whole cereals in urban Indian plates.

Sedentary lifestyle \& these trends have been one of the major causative factors of overweight \& obesity among Indians. In such scenario, we need to embed them way back in our plates as they have numerous benefits which are as follows:

I. They are a great source of Complex carbohydrate, Starch.

II. Because of such high intake, B complex requirement are met nearly to $60 \%$.

III. They also hence are good source of proteins, contributing nearly $30 \%$.

Table 1 Nutritive value of Cereals

\begin{tabular}{|c|c|c|c|c|c|c|c|c|c|}
\hline \multirow[b]{2}{*}{ Cereals } & \multicolumn{9}{|c|}{ Nutrients } \\
\hline & $\begin{array}{l}\text { Energy } \\
\text { (kcal) }\end{array}$ & $\begin{array}{l}\text { Starch } \\
(\mathrm{gm})\end{array}$ & $\begin{array}{l}\text { Protein } \\
\text { (gm) }\end{array}$ & $\begin{array}{l}\text { Fiber } \\
(\mathrm{gm})\end{array}$ & $\begin{array}{l}\text { Iron } \\
(\mathrm{mg})\end{array}$ & $\begin{array}{l}\text { Calcium } \\
\text { (mg) }\end{array}$ & $\begin{array}{l}\text { Magnesium } \\
\text { (mg) }\end{array}$ & $\begin{array}{l}\text { Potassium } \\
(\mathrm{mg})\end{array}$ & $\begin{array}{l}\text { Sodium } \\
\text { (mg) }\end{array}$ \\
\hline Amaranth & 355 & 59.33 & 13.27 & 7.49 & 8.02 & 162 & 270 & 413 & 2.81 \\
\hline Bajra & 347 & 55.21 & 10.96 & 11.49 & 6.42 & 27.35 & 124 & 365 & 4.11 \\
\hline Barley & 315 & 72.73 & 10.94 & 15.64 & 1.56 & 28.64 & 48.97 & 268 & 7.56 \\
\hline Jowar & 333 & 60.96 & 9.97 & 10.22 & 3.95 & 27.6 & 133 & 328 & 5.42 \\
\hline Ragi & 320 & 62.13 & 7.16 & 11.18 & 4.62 & 364 & 146 & 443 & 4.75 \\
\hline
\end{tabular}

Source: Indian Food Compostion Tables, 2017, NIN, ICMR

\author{
Volume 8 Issue 6 - 2018 \\ Ushma Haria \\ College of Home Science, Nirmala Niketan, India
}

Correspondence: Ushma Haria, College of Home Science, Nirmala Niketan, India, Email ushmaheria@hotmail.com

Received:September 17, 2018 | Published: November 30, 2018

IV. They are great source of Fiber (insoluble \& soluble), which delays gastric emptying, hence providing satiety, stabilizing blood sugar levels.

V. They have good amount of Magnesium \& potassium too, to be prescribed as DASH diet for hypertensive, as they help in vasodilation.

VI. They are low in Sodium \& high in Potassium, can be great prescription for Hypertensive.

VII. They are Gluten Free and also contain antioxidants like Carotenoids, Polyphenols.

(Table 1) They have hence been termed/ coined recently as "Superfoods" and/or "Next generation smart food" 
Additionally, they are farmer friendly too, as they require less water, chemicals, land \& are very economical to grow. Indians can replace high end cereals like Oats with Barley \& Quinoa with Amaranth seeds, to cut down the expense, as their benefits \& property are equivalent.

One needs to slowly introduce these different variants in moderation.

There is also a belief that millets shouldn't be consumed in summer is not true. They have high thermogenic effect because of high fiber content. This property aids in weight loss as it increases the energy consumption.

Millets being versatile can be easily incorporated in our diet. Age old ways of making Rotla/Bhakri can be used in interesting ways to make international dishes by using it as base for Pizza's, Frankies, Quesadilla. They can also be used to make other international dishes like Risotto, Salads, Granola bars, Cutlets, Soups etc. they can be used for Indian delicacies like porridges, paratha, khichdi, pancakes, Bakery products (Breads/Biscuits), Sweets like Ladoos, Halwa, Kheer, Southindian delicacies like Dosas, Idli, Upma, Idli, Pongal etc. they have also been used to make baby foods (supplementary/ complementary foods).

Having unpolished millets at least 4 times a week along with other interventions of weight management aids in tackling worldwide problems of Obesity.

This also prevents further risk of Overweight \& Obesity, \& therefore prevents other co existing morbidities with obesity.

\section{Acknowledgments}

None.

\section{Conflicts of interest}

Author declares that there is no conflict of interest. 